\title{
Når pasienten nekter blodoverføring
}

\author{
Leger kan bli stilt overfor et profesjonsetisk dilemma når de møter pasienter som nekter blod eller \\ blodprodukter på grunn av en alvorlig overbevisning. Her står det mye på spill, både for lege og pasient \\ og for pasientens familie.
}

\author{
Marianne Bahus \\ marbahus@online.no \\ Reidun Førde
}

Kronikken er en utvidet versjon av en artikkel som tidligere har stått $i$ Fadrelandsvennen (1).

Leger må være bevisste på hvilke profesjonsetiske grenser de skal sette for sin egen praksis (2). Det skal forventes høy etisk bevissthet i forhold til eget fag og egen rolleutøvelse. Det innebærer blant annet at den enkelte lege skal bli respektert for egne standpunkt i verdispørsmål og for sin oppfatning av hva som er fagetisk forsvarlig, dog innenfor rammene av faglig forsvarlig og omsorgsfull praksis (1). Lovbestemte begrensninger eller inngrep i profesjonsutøveres rollemoral er betenkelig og bør debatteres i lys av behovet for en egen profesjonsetikk.

Det bør være mulig å utforme lovbestemmelser som aksepterer legene som profesjonsutøvere med faglig og etisk overbevisning uten å måtte krenke pasientenes rett til å bestemme over seg selv. Likevel har lovgiverne ikke alltid lyktes med denne utfordringen, blant annet når det gjelder pasienters rett til å nekte å motta blod eller blodprodukter grunnet alvorlig overbevisning.

\section{Pasienters rett til å nekte blod}

En pasient har med hjemmel i pasient- og brukerrettighetsloven $\S 4-9$, første ledd rett til å nekte å motta blod eller blodprodukter på grunn av alvorlig overbevisning (3). Det rettslige kravet om «alvorlig overbevisning» forutsetter både en viss fasthet og varighet. Den alvorlige overbevisningen må videre fremstå som en selvvalgt og rasjonell forestilling og ikke være et utslag av for eksempel en psykiatrisk tilstand (4). I praksis er unntaket mest aktuelt for pasienter som er medlemmer av trossamfunnet Jehovas vitner. En utfordring for leger kan være å vurdere om nektelsen til unge voksne trosmedlemmer som synes å være under sterk innflytelse fra voksne trosledere, er et klart uttrykk for alvorlig overbevisning og ikke et utslag av frykt eller lydighet. Videre kan det være vanskelig å avgjøre hva som er en «rasjonell» forestilling.

Retten til å nekte å motta blod og blodprodukter gjelder også uavkortet i øyeblikkelig hjelp-situasjoner, jfr. helsepersonelloven $\S 7$ (5).

\section{Pasientautonomi og profesjonsansvar}

Selvbestemmelsesretten skal stå sterkt, og det synes også som en god regel å respektere pasientens alvorlige overbevisning. Bestemmelsen i pasient- og brukerrettighetsloven § 4-9 kan likevel kritiseres både $i$ et juridisk og etisk perspektiv.

Dersom pasienten i forkant av en situasjon der det kan bli aktuelt med blodoverføring tilkjennegir sin overbevisning, gir det legen valgfrihet til å akseptere dette eller henvise til en annen lege som kan akseptere premisset (6). Det gir pasientene trygghet om at de ikke får en medisinsk behandling som er i strid med deres overbevisning. Samtidig ivaretas legenes fagetiske integritet.

Generelt vil leger i dag strekke seg svært langt for å imøtekomme pasientens ønske om å avstå fra blod. Der risikoen for betydelig blodtap i forbindelse med inngrepet er stor, for eksempel noen former for organtransplantasjon, er vårt inntrykk at et forhåndsløfte ofte er problematisk for de som har ansvar for transplantasjonen. Jusprofessor Marit Halvorsen ved Institutt for offentlig rett, Universitetet i Oslo, mener at det ikke er mulig «å harmonisere legens plikt til å utøve sin virksomhet forsvarlig med pasientens rett til å instruere legen om ikke å gjøre det som $i$ en gitt situasjon er lege artis» (7).

Problemet settes på spissen i en øyeblikkelig hjelp-situasjon der pasienten vil dø uten blodtilførsel. Legen som er på vakt har en handlingsplikt i slike situasjoner, men pålegges av loven å ikke behandle pasienter som av overbevisningsgrunner ikke ønsker blodoverføring. Legen tvinges da til å velge mellom enten å følge loven eller sin egen faglige og etiske overbevisning (1). I dag er dette et alvorlig etisk problem for mange leger i kirurgiske fag.

Sett fra et profesjonsetisk, og kanskje også allmennetisk standpunkt, oppleves det problematisk at en lege i verste fall kan miste autorisasjonen for å ha reddet liv. Det er reist spørsmål ved om regelen i pasientog brukerrettighetsloven $\S$ 4-9 heller må forstås slik at den som nekter å motta blod samtidig gir avkall på behandling der blodoverføring vil være det eneste riktige under gitte omstendigheter (7).

\section{Juridiske utfordringer}

Regelens juridiske utfordringer gjelder uavhengig av om det foreligger en øyeblikkelig hjelp-situasjon. Det følger av pasient- og brukerrettighetsloven $\S 3-1$, første ledd at en pasient har rett til å medvirke ved valg mellom tilgjengelige og forsvarlige undersøkelses- og behandlingsmetoder. Pasientens mulighet til å samtykke til selve operasjonen og samtidig reservere seg mot blod eller blodprodukter dersom det skulle oppstå et behov for dette, innebærer etter vår oppfatning en rett til å si ja til deler av en behandling og nei til en annen del, som kan være nødvendig for å utgjøre en forsvarlig behandlingsmetode. Medvirkningsretten gir kun rett til å velge mellom forsvarlige behandlingsmetoder, ingen rett til å velge deler av en behandling som alene kan være uforsvarlig.

Å kunne nekte å motta blod grunnet alvorlig overbevisning harmonerer videre dårlig med kravet helsepersonell har til faglig forsvarlig utøvelse av yrket i helsepersonelloven $\S 4$. Pasienten ønsker en del av en faglig prosedyre, men nekter en annen kanskje helt nødvendig del for at inngrepet skal være vellykket. À operere en pasient med et slikt premiss er å akseptere at pasientene făr definisjonsmakt over hva som er faglig forsvarlig helsehjelp i en situasjon der blodtilførsel er medisinskfaglig nødvendig. Marit Halvorsen har uttrykt at lovbestemmelsen «ser ut til å gi pasienten en rett til å instruere legen om å utøve sitt fag på en ikke forsvarlig måte» (7). Lovbestemmelsen om å kunne nekte å motta blod grunnet alvorlig overbevisning i pasient- og brukerrettighetsloven § 4-9, første ledd samsvarer dermed ikke med medvirkningsretten gitt i $\S 3-1$, og i visse situasjoner heller ikke med helsepersonelloven $\S 4$ og profesjonsetiske føringer.

Det er akseptabelt at noen leger er villige til å utføre en prosedyre med et bindende løfte til pasienten om at det ikke skal gis 


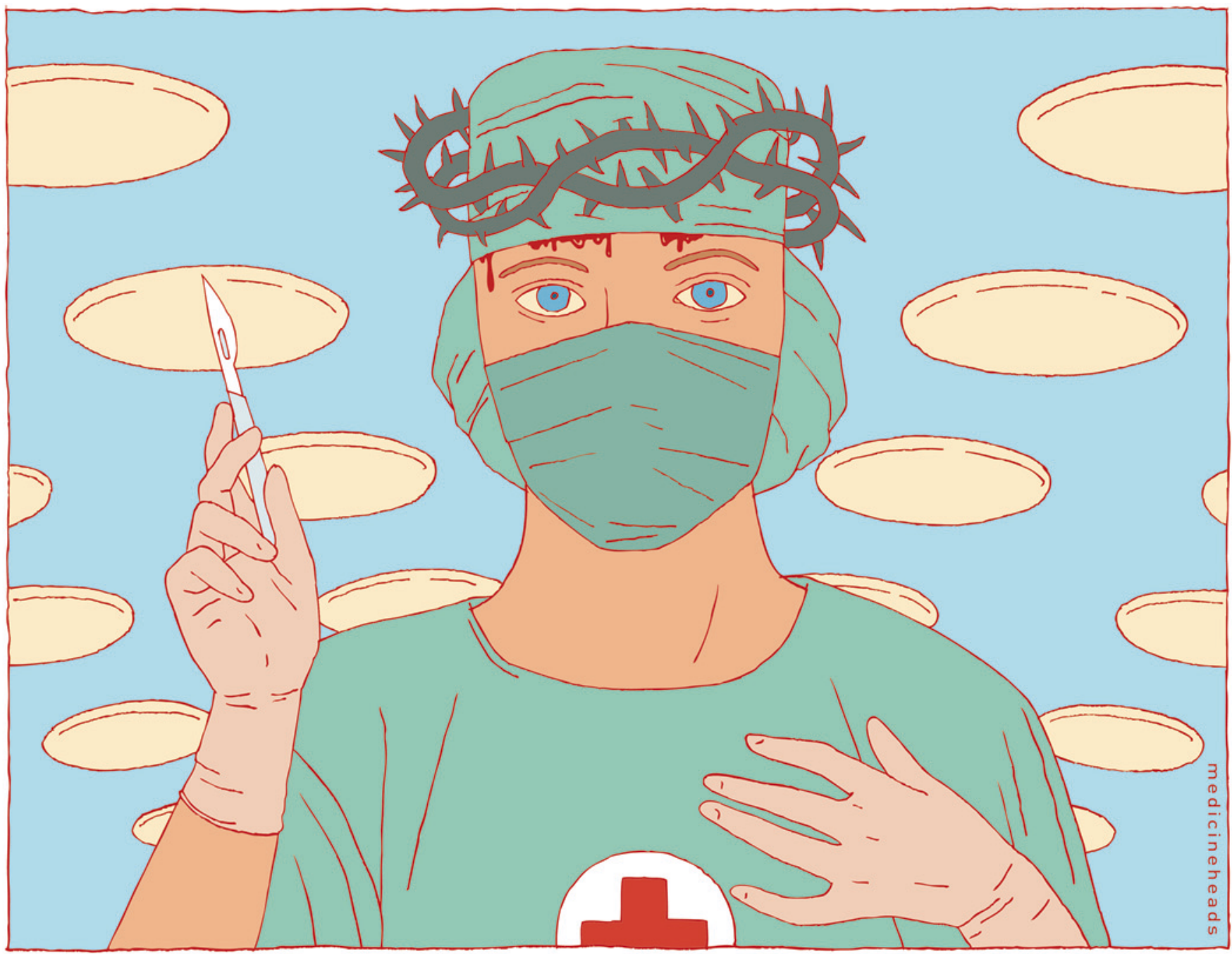

Illustrasjon ๔ Trond Nordahl/Medicineheads

blod. Det som derimot ikke er akseptabelt, er at leger som ikke ønsker å utføre en prosedyre med et slikt løfte, ikke har et reelt valg i øyeblikkelig hjelp-situasjoner.

\section{Harmonisering}

En kritikk av bestemmelsen om pasienters rett til å nekte å motta blod på grunn av alvorlig overbevisning handler ikke om manglende respekt for denne pasientgruppens valg. Selvbestemmelsesretten skal stå sterkt. Spørsmålet er om selvbestemmelsesretten kan praktiseres på en måte som gjør at legene ikke blir tvunget til å handle i strid med sin fagetiske overbevisning. Videre spør vi om det er ønskelig med en lovbestemmelse der pasienten kan kreve en behandling som samlet fremstår som uforsvarlig (1).

En mulig løsning på dette rettslige og etiske dilemmaet er det refererte tolkningsalternativet, at den som nekter å motta blod også gir avkall på behandling der blodoverføring under gitte omstendigheter vil være det eneste forsvarlige (7).

\section{Profesjonsetikk i helselovgivningen}

Et kultur- og verdipluralistisk samfunn kombinert med en styrking av pasientrettighetene stiller stadig større krav til at leger må utvise toleranse og respekt på den ene siden og samtidig sette etisk og juridisk akseptable grenser for sin virksomhet.

Legene kan være tjent med at det fokuseres enda tydeligere på behovet for en sterk og synlig profesjonsetikk. Helselovgivningen bør på sin side være utformet slik at lovteksten og tolkningen av denne ikke går på bekostning av verken pasientenes rett til selvbestemmelse eller legenes faglige og etiske integritet som profesjonsutøvere.

\section{Marianne Bahus (f. 1973)}

er advokat i advokatfirmaet Bahus.

Forfatter har fylt ut ICMJE-skjemaet og oppgir ingen interessekonflikter.

\section{Reidun Førde (f. 1950)}

er lege og professor i medisinsk etikk. Hun har faglig ansvar for kompetanseoppbygging av kliniske etikk-komiteer og arbeider tverrfaglig inn mot klinisk praksis.

Forfatter har fylt ut ICMJE-skjemaet og oppgir ingen interessekonflikter.

\section{Litteratur}

1. Bahus MK. Profesjonalitet, integritet og nøytralitet. Fædrelandsvennen 7.5.2013.

2. Ruyter KW, Førde R, Solbakk JH. Medisinsk etikk en problembasert tilnærming. Oslo: Gyldendal Norsk Forlag 2000: 78

3. LOV-1999-07-02-63. Lov om pasient- og brukerrettigheter (pasient- og brukerrettighetsloven). http://lovdata.no/dokument/NL/lov/1999-07-02-63 (20.2.2014).

4. Syse A. Pasientrettighetsloven med kommentarer. Oslo: Gyldendal Akademisk, 2009: 339

5. LOV-1999-07-02-64. Lov om helsepersonell m.v. (helsepersonelloven). http://lovdata.no/dokument/ NL/Lov/1999-07-02-64 (20.2.2014).

6. Ot.prp. nr. 12 (1998-1999) Lov om pasientrettigheter (pasientrettighetsloven).

7. Halvorsen M. Pasienter som nekter behandling Tidsskr Nor Lægeforen 2002; 122: 323-4. 